\title{
АКЦЕНАТСКИ СИСТЕМ СРПСКИХ ГОВОРА У РУМУНИЈИ (ПОЉАДИЈА)
}

На основу теренских истраживања обављених на територији Пољадије у Румунији, у местима Златица, Соколовац и Ланговет, прикупљен је материјал који је послужио за анализу прозодијских карактеристика говора поменутих места. Циљ овог рада јесте потпунији опис инвентара и дистрибуције прозодема пољадијских насеља, при чему ће се утврдити и однос овог говора према суседним говорима. На основу индекса фреквенције прозодијских особина у идиолектима говорника са овог подручја, покушаћемо да утврдимо фазе нарушавања акценатског система и крајње резултате његове балканизације, где под балканизацијом подразумевамо нарушавање српског прозодијског система под утицајем неког балканског језика.

Кључне речи: српски говори у Румунији, Пољадија, прозодија, акценатски систем, интерференција.

\section{1. Увод}

Пољадија или Белоцркванска котлина представља географску област, која се налази у котлини реке Нере, смештене између Банатских планина у данашњој Румунији и Вршачког брега у Србији. ${ }^{3}$ Главни центар ове области у Србији је Бела Црква, а наспрам ње су смештена румунска пољадијска насеља.

Соколовац, Златица, Луговет, Прњавор и Лесковица су насеља у којима живе или су до скоро живели махом Срби као већинско становништво. Ова насеља се налазе на обали реке Нере, смештена су у равничарском делу југозападног Баната. Некада су ова насеља улазила у састав географског појма „Клисура“, а тај назив налази се и на карти генерала Мерција из 1723-

\footnotetext{
${ }^{1}$ aleksandra.loncar.raicevic@filfak.ni.ac.rs

${ }^{2}$ Овај текст настао је као резултат рада на пројектима Истраживање кутуре и историје Срба у Румунији, који се реализује уз помоћ Центра за научна истраживања и културу Срба у Румунији при Савезу Срба у Румунији и Српски језик некад и сад: лингвистичка истражсивања (ФФ 360/1-16-10-01) који се реализује у оквиру Филозофског факултета Универзитета у Нишу.

${ }^{3}$ https://sr.wikipedia.org/wiki/Пољадија
} 
1725. године. Познати истраживач ових насеља Александар Станојловић употребљава назив Банатска клисура што је и „најприкладнији назив јер у склопу овог топонима нема назива главне реке у овој клисури, тј. Дунава“. У то време није се правила разлика између Пољадије и Клисуре, чак и назив Дунавска клисура може бити рашчлањен на два дела, који је обухватао географски простор од Базјаша до Турн Северина, дужине 142 километра ${ }^{4}$.

У раду „Банатске Хере“ М. Филиповића овим именом се називају становници места на левој страни Нере која се налазе у саставу Румуније: Лесковица, Ланговет, Златица и Соколовац, као и становници Калуђерова, Крушчице, Кусића, Црвене Цркве, Врачевог Гаја и Паланке, на десној страни Нере, у Белоцркванском срезу. Ивић у раду Место банатског херског говора међу српским дијалектима наводи да у недостатку подробних података о говорима југоисточног Баната једни аутори ове говоре сврставају у косовско-ресавске, други у шумадијско-војвођанске (Ивић 1958: 327), управо због нејасно одређених дијалекатских граница. Тако је нпр. описујући говор Крушчице, на српској страни, Ивић констатовао да не припада ни косовскоресавском ни шумадијско-војвођанском дијалекту, што се убрзо показало за целу банатску херску област, чак за цео југоисточни Банат (Ивић 1958: 327).

Клисурске говоре, који су у најближем суседству пољадијских говоpa, П. Ивић сврстава у смедеревско-вршачки дијалекат (Ивић 1999: 331), који одликује комбинација старије акцентуације и шумадијско војвођанске замене јата (Ивић 1999: 328). За разлику од Ивића, Томић све клисурске и пољадијске говоре, осим говора Свиничана, сврстава у косовско-ресавски дијалекат. М. Окука српска насеља у Банатској клисури, на румунској страни, дуж Дунава, југоисточно од Беле Цркве такође сврстава у косовско-ресавске говоре (Окука 2008: 199).

\footnotetext{
${ }^{4}$ Соколовац, у народу познатији као Сакаловац изграђен је на левој обали Нере у близини њеног ушћа у Дунав. Први пут се спомиње под називом Solmos (соко) још 1472. године што га сврстава у ред најстаријих српских насеља са ових простора. Данас је Соколовац општинско место и у састав општине улазе насеља: Златица, Прњавор, Луговет и Базјаш. Према последњем попису становништва из 2011. године 436 становника су се изјаснили као Срби, а осталих 213 као Румуни. Златица се спомиње још 1152. године, што значи да је најстарије српско насеље у Дунавској Клисури и Пољадији. Данашња Златица је смештена на левој обали Нере, уз саме обронке Локве, док се место раније налазило два км удаљено од ове локације. У опису вршачко-карансебешке епархије од 1713. године место је имало 30 домова. У периоду од 1829. до 1840. године назива ce Szlatieza, касније, у доба Мађарске је имала мађаризовани назив, Neraaranyos, а тек после Првог светског рата 1920. године добила je румунски нзив Zlatita. У последњем попису становништва, 20. октобра октобра 2011. године 210 становника су се изјаснили као припадници српске мањине, а 410 становника као Румуни.
} 


\section{2. Акценатски систем}

Циљ овог рада јесте потпунији опис инвентара и дистрибуције прозодема у говору пољадијских насеља при чему ће се утврдити и однос овог говора према суседним говорима. На основу индекса фреквенције прозодијских особина у идиолектима говорника са овог подручја, покушаћемо да утврдимо фазе нарушавања акценатског система и крајње резултате његове балканизације, где под балканизацијом подразумевамо нарушавање српског прозодијског система под утицајем неког балканског језика. Опште је познато да ће у сусрету компликованијег и једноставнијег система доћи до прилагођавања првом према другом.

Интерференција у дијалекатским прозодијским системима може настати у сусрету једног дијалекта са другим, са стандардом и са неким од балканских језика (Бошњаковић 2014: 7). У сусрету два дијалекта, оног са старом и оног са новом акцентуацијом, обично ће се у првом започети процес померања силазних акцената ка почетку речи (ло̀nата : лопӓта); у сусрету неког од старосрпских дијалеката и стандарда може доћи до прихватања само новог места акцента или са силазном интонацијом (профёсоре > npöфecope : npòфесоре), а код говорника са експираторном интонацијом и појаве хиперкорекције или дужења (про́фесоре). Српски говори у контаку са другим балкансим језицима такође имају нарушен прозодијски систем ${ }^{5}$, o чему сведоче радови у којим се анализирају српско-албански језички односи (Станишић 1995); српски говори у контакту са мађарским, румунским и словачким језиком (Степановић 1994) ${ }^{6}$ и српски говори у контакту са мађарским (Милорадовић 2007). ${ }^{7}$

\footnotetext{
${ }^{5}$ Анализирајући српско-албанске језичке односе Вања Станишић наводи измене на утицаје на прозодијском плану у зетско-сјеничким, косовско-ресавским и призренско-јужноморавским говорима који су изложени албанском језику. На првом месту уочено је губљење тонских опозиција, тј. замена дугоузлазног акцента догосилазним (гла́ва > гла̂ва, на̂род) у говору Озринића, Комана, Загарача и Вучитрна; у метохијском и мрковићком говору на месту краткосилазног јавља се дугосилазни (жӥто > жйто) (Станишић 1995: 47-48)

${ }^{6}$ Српски говори у Мађарској под утицајем најпре мађарског, а затим и румунског и словачког језика имају нарушен прозодијски систем који се огледа у дужењу кратких акцената (стӓница $>$ стаิний), скраћивању дугих акцената (ру́чак > рйчак) и силазним акцентима уместо узлазних (госпо̀дин > госпӧдин) (Степановић 1994: 120).

${ }^{7}$ Велики број радова о прозодијској интерференцији и њеном утицају на формирање страног акцента потврђују актуелност и оправданост бављења овим проблемима у језику. Зачетници ове традиције у руској школи су група фонетичара Лењинградске научне школе лингвистике на челу Л. Р. Зиндером и Л. В. Бондарком који су истакли важност фонолошких истраживања за развој систематског приступа проучавања говорне активности (Nikolaev, Parfenov, Artemiev 2015). Дела А. Метлука сматрају се веома иновативним у области проучавања интеракције прозодијских система језика и у њима су формулисане теоријске основе и методолошки принципи проучавања прозодијске интерференције. Фенеомен билингвизма или двојезичности многи научници сматрају неодвојивим од интерференције U. Weinreich,
} 
У раду ће бити презентован прозодијски материјал разврстан на основу судбине акцената у следећим позицијама:

1. Краткосилазни акценат иза неакцентоване краткоће (на отвореној и затвореној ултими);

2. Краткосилазни акценат у медијалној позицији;

3. Дугосилазни акценат иза неакцентоване краткоће (на отвореној и затвореној ултими);

4. Дугосилазни акценат у медијалној позицији иза краткоће;

5. Краткосилазни акценат иза неакцентоване дужине (на отвореној и затвореној ултими);

6. Краткосилазни акценат у медијалној позицији иза неакцентоване дужине;

7. Дугосилазни акценат иза неакцентоване дужине (на отвореној и затвореној ултими);

8. Дугосилазни акценат у медијалној позицији иза неакцентоване дужине.

Посебно ће бити разматране појаве као што су: скраћивање дугосилазних акцената у крајњем отвореном слогу, дужење у емфази и експираторни акценат.

\section{1. Судбина краткосилазног акцента иза неакцентоване краткоће (на отвореној и затвореној ултими:}

\section{Тип сестра̀}

Померањем краткосилазног акцента са отворене ултиме на неакцентовану краткоћу у већини примера у овом говору извршено је метатаксичко преношење и добијен је краткосилазни акценат:

жёна, жёне, зёмља, сёло, сёстра, слйжба; дӧшла, дӧшло, ӥшло, пӧшла; јёдна, юёму.

\section{Тип човёк}

Померањем краткосилазног акцента са последњег затвореног слога на претходну неакцентовану краткоћу најчешће је добијен краткосилазни акценат. Метатаксичко преношење забележено је у примерима:

жӥвот, јӓстук, јёдан, јёдна, јёзик, кӓлуп, ӧтац, тӧчак, ӱнук, чёкић, чӧвек; ийьат;

Познато је да код новоштокавских говора код којих се преношење

L.V. Shcherba, R. Jacobson, E. Haugen, A. Martin, L.I. Barannikova, N.A.Lyubimova, A. A. Metluk, G.N. Vishnevskaya, J.A. Dubovsky, A.B. Mishin, L.G. Fomichenko, G.N. Chirsheva, I.G.Bubnov, A.I. Rabinovich, Yu.A. Zhlutenko, E.A. Filatova, N.V. Sukhova (Nikolaev, Parfenov, Artemiev 2015). Они сматрају да се интерференција манифестује на свим језичким нивоима, али је нарочито уочљива у фонетици, када је процес интерференције објективан и не зависи од воље говорника 
ограничава на ликвидацију окситогенезе краткосилазног акцента, нема сагласности у погледу акцента пренесеног на првобитно кратку ултиму. У неколико говора се јавља краткоузлазни акценат (нпр. васојевићки и бјелопавлићки), у другим многобројнијима - краткосилазни (на целој косовскоресавској територији) и најзад у низу говора имамо кановачки акценат. На основу нашег материјала, у говорима Пољадије присутна је тенденција као у косовско-ресавском. Мада, Ивић наводи да се у херском говору у овом положају поред краткосилазног јавља и кановачки акценат - жёна, ӥшла, ӱнук; о́и̧а, ко́ња, све́кра (Ивић 1958: 328), што је забележено и у нашој грађи (ба́бу, де́ц̧а, же́не, ма́ми, се́стра ћóшку, до́шла), али у знатно мање примера него што је то био случај у Дунавској Клисури. ${ }^{8}$

\section{Тип мотйка}

Краткосилазни акценат у медијалној позицији иза неакцентоване краткоће у говору пољадијских насеља се веома добро чува, што иначе и представља једну од карактеристика говора са старијом штокавском акцентуацијом. Као илустрацију наводимо део забележене грађе:

аљиине, градйна, грабӱља, владйка, детёта, држӓву, држӓва, женӓма, Златӥца, Србӥја, Србӥје, Србӥју, Илӥја, камӓра, камӓре, капӥја, капӥју, касӓпин, кецёљь, кобйле, кревёти, крмӓча, кудёља, кутӥја, куруиза, лопӓта, молӥтве, Мирјӓна, Молда̄ва, недёља, Никӧла, овцайма, орӓси, поклӓде, ракӥја, Решӥца, рукӓма, ручйцуа, столӥца, телёта, товӓри, унӱку, Ускр̈са, фурӥне, ципёле;

волёо, белёжи, говӧри, говӧру, горёли, дочёка, женйли, имӓли, имаัо, исёко, истёра, обёре, одвёзем, одмӧри, огрӥзне, ожёниш, остӓло, остӓне, отвӧрен, отёрам, отӥно, отӥшли, погйнеш, појёду, покйсне, покуипим, помӧгнем, почйстим, прекёсти, пропӓла, родйла, родйло, седёо, седёли, сванйла, склопйли, товӓри, убйли, увӓти, узймо; готӧво; четӥри; његӧве; годӥшњи, пролёћно.

Без обзира на то што се краткосилазни акценат добро чува у медијалној позицији иза краткоће, забележен је и одређени број примера са метатаксичким преношењем: др̈жали, ӥграли, пӧзнали; жёнама.

\section{2. Дугосилазни акценат иза неакцентоване краткоће (на отвореној и затвореној ултими) и дугосилазни акценат у медијалној позицији иза краткоће}

\section{Тип болиิ}

Дугосилазни акценат иза неакцентоване краткоће у финалном слогу показује велику стабилност, о чему сведоче примери:

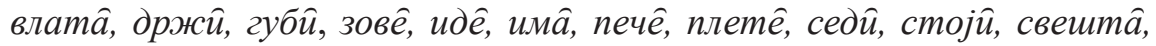

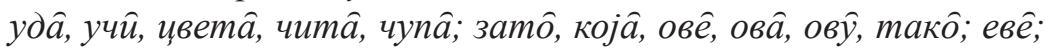

\footnotetext{
8 Лончар Раичевић 2018.
} 
Међутим, у овој позицији могуће је и померање дугосилазног акцента на претходни слог и тада се се акценат реализовао као краткосилазни:

вӧде (Гјд), зёмље (Гјд); бёре (3. л. през), кӧпа (3. л. през), плёте (3. л.през), цирта (3. л. през).

\section{Тип аста̂л}

У затвореном финалном слогу, такође је стабилан дугосилазни акценат:

Банаิт, бунаิр/бйнар, вагоิн, дућаิн, занаิт, комиิн, колаิч, косаิч, круњаิч, лекаิр, ораิч, паркеิт, пасүิљ, пешкиิр, проблеิм, сејаิч, сељаิк, сокаิк, иртаิк, шофеิр; бојиิш, држиิш, крстиิш, немоิj, продаิш, седиิш, учиิш; данаิс, напреิд ноћâc, озгоิр; четре̂с; оваิj, онаิj, његоิв; такоิ така̂в, али се ипак бележе и примери са метатаксичким преношењем после скраћења: бӥдак; ймам, ӥмам, ӥмащ, зӧвем, кӧпам, кӧпащ.

\section{Тип девоิјка}

Дугосилзни акценат у медијалној позицији иза неакцентоване краткоће је веома стабилан у овим говорима о чему сведоче примери:

ареิнда, девојке, девојјку, колеิчке, љуљаิике, ораิње, печуิрку, прсте̂ње, Румуิнка, седеิљку; идүิће, јесеิње, једиิно, домаิћа, десеิти, кућеิвни, метаิлни, могуิћи, румуิнски; завеюжем, забраิзди, заврิшен, запаิли, изглебда, изићћем, корйсте, облаิчим, обуิвам, отиิднем, отваิра, повеิзан, разиิђе, ужиิва; којиิма;

\section{3. Судбина краткосилазног акцента иза неакцентоване дужине (на отвореној и затвореној ултими)}

Као и у већини новоштокавских говора са непренесеном акцентуацијом краткосилазни акценат је повучен са последњег слога.

\section{Тип де̄тё}

Померањем краткосилазног акцента са отворене ултиме на неакцентовану дужину добија се дугоузлазни акценат, што потврђују примери.

ба́шта, бра́зда, ва́рош, ве́дро, во́јска, вре́ме, ба́шта, бра́на, гле́то, ду́ша, зимма, ја́рма, ко́лца, ла́нац, кље́шта, ло́нче, мле́ко, Не́ра, па́рлог, пи́саи, ру́чак, сви́ла, слу́zа, стра́на, Шва́ба, итру́дла.

\section{Тип на̄рӧд}

Померање краткосилазног акцента са затворене ултиме на неакцентовану дужину забележено је само у једном примеру: ра́зред. Иначе се у овој позицији најчешће чува старо акценатско стање:

Боржӥћ, за̄твӧр, наррӧд, про̄зӧр.

\section{Тип пйтаัли}

Краткосилазни акценат иза неакцентоване дужине у већини примера чува се у медијалној позицији:

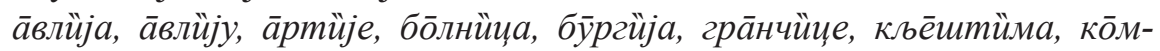

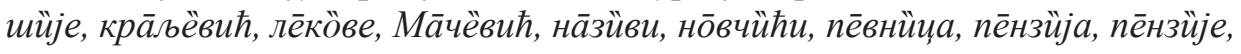




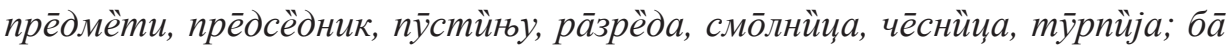

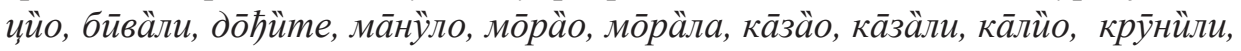

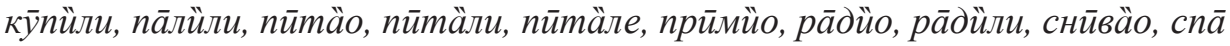

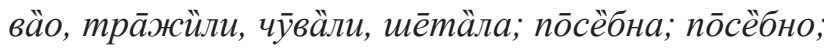

$\mathrm{У}$ великом броју примера под утицајем румунског језика долази до промене дугоузлазног у дугосилазни акценат, што спада у одлику која је обична и честа у говорима који су изложени румунском језику (Ивић 1990: 191-192).

Разни занатти су били у село.// Морали смо да идемо у рекку./ Видите какво је дошло времме.// Кад отиднем код лека̂pa.// Он сваки петтак дође.// Немаш плаิту.// Све је пуิсто.// Немаш плуг, немаш браิну.// Имао сам проблеิме.// Све по ре̂ду.// Траิву имам фину.// Имали смо машиิну.// Идем да купим цигаิре.//Велика траิва.// Живот теюжак смо имали. То су стари алаิти.// Оне су окрузле.// Прстење од метаิла.// Биิло пра прошло.// Прйчају људи.// Преко путта Златице.

Ова појава је запажена и у југоисточном Банату (Ивић 1957: 32). Тамо дугосилазни акценат долази уместо створеног дугоузлазног и употребљава се свуда паралелно са њим (Ивић 1957: 33). Узроци промене леже у чињеници да се јавља око румунске границе „обично у селима где има становништва румунског порекла, и продире напоредо са низом румунских особина у синтакси“ (Ивић 1957: 33). Ивић сматра да је на разликовање силазних и узлазних акцената разорно деловала фонетика румунског језика који познаје само једну интонацију“ (Ивић 1957: 33), па тако као и у случају говора Галипољских Срба узрок ове појаве лежи у симбиози са несловенским живљем, које не прави разлику између силзне и узлазне интонације.

Иначе је познато да се у штокавским говорима догосилазни акценат уместо дугоузлазног јавља по правилу дуж ивице наше етничке територије: у Славонској Подравини, у вучитрнском крају, у галипољском говору, што никако не може бити „плод случаја, па је очевидно да бар на некима од тих места узроке укидању интонационих опозиција треба тражити у међујезичком контакту“ (Ивић 1958: 328).

\section{4. Дугосилазни акценат иза неакцентоване дужине (на отвореној и затвореној ултими) и дугосилазни акценат у медијалној позицији иза неакцентоване дужине.}

\section{Тип вӯче̂}

Иако је процес померања на отвореној ултими иза дуге пенултиме захватио ове говоре: дýme, (Гмн), љу́́ди (Гмн), ипак доминирају примери са старијим стањем:

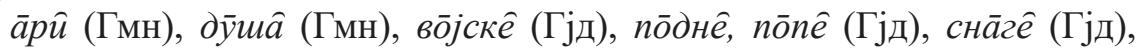

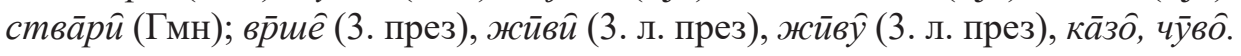




\section{Тип вўче̂ш}

У затвореном слогу иза дуге пенултиме јављају се искључиво примери са непренесеним акцентом:

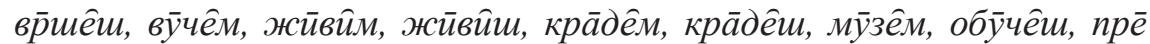

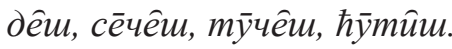

\section{Тип вршшеммо}

Дугосилазни акценат у медијалној позицији иза неакцентоване дужине показује велику стабилност:

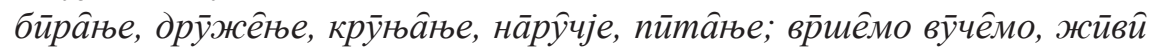

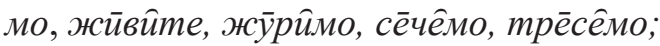

Међутим, забележени су и примери у којима се дугосилазни акценат

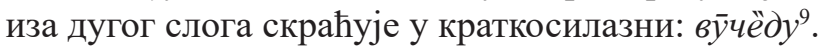

\section{5. Експираторни акценат}

У појединим примерима у којима је уочено скраћивање акцената, може се претпоставити постојање експираторног акцента: дӓн, грӧбље, кра̄j, шкӧлу; кӓжем;

Слична запажања у вези са експираторним акцентом бележи Ж. Бошњаковић у говору источне Шумадије и С. Милорадовић у говору Белобрешке (Милорадовић 2007).

\section{2. Закључне напомене}

У погледу акцентуације овај говор спада у групу старијих новоштокавских говора, оних који силазне акценте ван првог слога речи углавном чувају непренесене.

Инвентар прозодема подразумева троакценатски систем са сачуваном предакценатском дужином и радикално скраћеним квантитетом иза акцента, па у том погледу овај говор иде паралелно са косовско-ресавским дијалектом.

Дистрибуција акцената је следећа:

1)Краткосилазни се среће на првом и унутрашњем слогу акцентованих речи (сёстра, клисӱра);

2) Дугосилазни се налази на свим слоговима у речи (пеิнщер, жӯ̄pûмо, астаิл);

3) Дугоузлазни се може наћи само на пенултими (во́јске, па́рлог).

Анализа прозодијских одлика говора Пољадије показала је, с једне стране, да овај говор поседује типичне одлике косовско-ресавске акценту-

\footnotetext{
${ }^{9}$ Према Ивићевом материјалу, у Крушчици и Врачевом Гају такође долази до скраћивања дугосилазног акцента у краткосилазни (Бого̄jављьйье, nūmäне).
} 
ације, а са друге, да су у њему започети процеси разградње акценатског система, чему доприноси специфична ситуација у којој се говор Пољадије налази као српски говор у несловенском окружењу.

\section{Литература}

Бошњаковић, 2008: Ж. Бошњаковић, Фонетске особине говора источне Шумадије. Српски дијалектолошки зборник LV. Београд, 1-322.

Бошњаковић, 2014: Ж. Бошњаковић. Фазе и резултати балканизације прозодијског система у говорима шумадијско-војвођанског дијалекта Срба у Румунији, IWoBA VIII, Реферати VIII међународног скупа о балтословенској акцентологији, Славистички зборник, Нова серија, књига I. Нови Сад, 7-16.

Ивић, 1957: П. Ивић, О говору галиполских Срба у: Српски дијалектолошки зборник, XII Београд: Српска академија наука, Институт за српски језик, $1-520$.

Ивић, 1958: П. Ивић, Место банатског херског говора међу српским дијалектима, Банатске Хере, Војвођански музеј, Посебне издања, Нови Сад, 326-353.

Ивић, 1999: П. Ивић, Српски дијалекти и ґихова класификащија (II). Нови Сад: Зборник Матице српске за филологију и лингвистику, XLII, 303-354.

Ивић, 2001: П. Ивић, Дијалектологија српскохрватског језика. Увод у штокавско наречје, у: Целокупна дела, II, Издавачка књижарница Зорана Стојановића, Сремски Карловци - Нови Сад.

Ивић и др. 1994: П. Ивић, Ж. Бошњаковић, Г. Драгин, Банатски говори шумадијско-војвођанског дијалекта. Српски дијалектолошки зборник $X L$, Београд $1-419$.

Лончар Раичевић, 2017: А. Лончар Раичевић, О акценатским карактеристикама српских говора у Румунији (говор Диьаша), Исходишта 3. Темишвар/ Ниш, 159-169.

Лончар Раичевић, 2018: А. Лончар Раичевић, О акиенатским карактеристикама српских говора у Банатској Клисури (Белобрешка), Исходишта 4. Темишвар/Ниш, 159-171.

Милорадовић, 2007: С. Милорадовић. И ракију пијем сас медом. Дијалекатска слика Белобрешке (Румунија). Probleme de filologie slavă, XV. Timişoara:Universitatea de Vest din Timişoara, 573-580.

Милорадовић, 2015: С. Милорадовић. Српски периферни говори - међујезички утицаји и балканистички процеси, Gwary Dzis - vol. 7, 71-82.

Николајев и др. 2015: A. Nikolaev, E. Parfenov, I. Artemiev. Foreign Language Accent and Prosody in the Context of Cross-cultural Multilingualism. Mediterranean Journal of Social Sciences, MCSER Publishing, , Vol6, No 6, S7, Rome - Italy, 242-247.

Окука, 2008: M. Okuka, Srpski dijalekti, Zagreb (SKD Prosvjeta). 
Пецо, 1989: A. Peco, Pregled srpskohrvatskih dijalekata, Naučna knjiga, Beograd 1989.

Радан, 2009: М. Радан. Иноваиије у српским говорима у румунском Банату у светлу језичке интерферениије (са посебним освртом на карашевске говоре). Научни састанак слависта у Вукове дане 38/1, Београд 289-302.

Радан, 2014: М. Радан. О акиенту најархаичнијих српских говора у румунском Банату (каратевски, свинички, банатско-ирногорски). IWoBA VIII, Реферати VIII међународног скупа о балтословенској акцентологији, Славистички зборник, Нова серија, књига І. Нови Сад.

Станишић, 1995: В. Станишић. Српско-албански језички односи. Српска академија наука и уметности. Балканолошки институт. Посебна издања 59. Београд: 156 стр.

Степановић, 1994: П. Степановић. Говори Срба и Хрвата у Мађарској. Штокавско наречје. Матица српска. Вукова задужбина, 171.

Aleksandra R. Lončar Raičević

\section{ABOUT THE ACCENTUAL CHARACTERISTICS OF THE VARIETY OF SERBIAN USED IN THE ROMANIA (POLJADIJA)}

Summary

Based on the field research carried out on the territory of the Poljadia in Romania, we have collected the material which was used in the analysis of the prosodic characteristics of the given variety. The paper presents the accentual system, including the inventory and the distribution of the prosodemes. One of the most prominent features of this variety is the Old-Shtokavian type of accentuation, i.e. the new system of three accents derived from the Old-Shtokavian inventory with two accents. 